\title{
Timing of Spawning of Wild Chum Salmon in a Non-enhanced River and their Seaward Migration in Northern Honshu, Japan
}

\author{
Masaya Iida, Yuta Yagi, and Tomoaki Iseki \\ Japan Sea National Fisheries Research Institute, Japan Fisheries Research and Education Agency, Chuou-ku, \\ Niigata 951-8121, Japan
}

Keywords: Chum salmon fry, Wild fish, Natural spawning, Seaward migration

Chum salmon (Oncorhynchus keta) have a wide geographic distribution around the northern Pacific Rim, with northern Honshu Island, Japan being located at the southernmost limit of their distribution (Salo 1991). Information on the ecology of wild chum salmon is needed for their sustainable management in Japan, as it enables the development and application of effective conservation measures (Miyakoshi et al. 2012; Nagata et al. 2012). Wild fish in this paper are considered to be fish that have reproduced naturally for more than one generation, regardless of parental origin (hatchery fish or wild fish) (Morita and Ohkuma 2015). We investigated the timing of spawning of wild chum salmon in a non-enhanced river and their seaward migration in the northern Honshu, Japan.

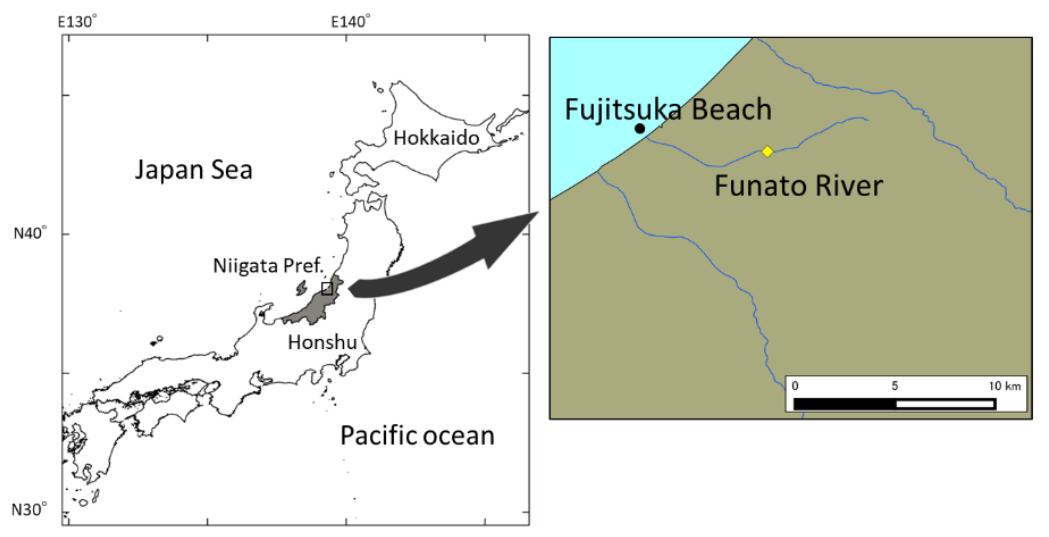

Fig. 1. Map showing the study area where chum salmon fry were collected in the surf zone of Fujitsuka Beach, and the study site where the spawning redds of chum salmon were observed in the Funato River, Japan.

The survey area was $1050 \mathrm{~m}$ and was established in Funato River where hatchery chum salmon fry had never been stocked (Fig. 1). Spawning redds were counted visually once every ten days from early October to early January in 2015-2018. The river temperature was recorded using a temperature logger. Chum salmon fry were collected from February to June at $0.4-0.8 \mathrm{~m}$ depth by using a small seine net $(2 \mathrm{~m}$ wide, $1 \mathrm{~m}$ deep mouth, $4.5 \mathrm{~m}$ long, with wing nets $1 \mathrm{~m}$ long and a central bag with a $1 \mathrm{~mm}$ mesh), in Fujitsuka Beach close to the mouth of Funato River (Fig. 1). Sea surface water temperature (SST) and salinity (SSS) were measured on each sampling date. A generalized linear model (GLM) with a binominal distribution was performed to evaluate the influence of SST and SSS on the presence-absence of the chum salmon fry.

Spawning redds were observed mainly from the middle of October to the middle of December. Chum salmon fry were collected mainly from early March to early May when SST and SSS ranged from $7.4^{\circ} \mathrm{C}$ to $17.5^{\circ} \mathrm{C}$ and $3.9^{\circ} \mathrm{C}$ to $32.7^{\circ} \mathrm{C}$, respectively. Most samples were under $40 \mathrm{~mm}$ in fork length $(38.0 \pm 3.7 \mathrm{~mm}, n=2038)$. The period that chum salmon fry were present mostly matched the timing of the emergence of the wild fry, which was estimated by the cumulative water temperature of Funato River. The GLM showed that the probability of chum salmon fry occurrence decreased with increasing SST and SSS. The model also predicted that the probability was $30.2 \%-62.5 \%$ even when the SSS ranged from 10 to 30 , and the SST was $15^{\circ} \mathrm{C}$ (upper thermal limits for chum salmon juveniles in Hokkaido; Irie 1990). Stocking of hatchery chum salmon fry ends by late March every year in northern Honshu, Japan.

The results suggest that the seaward migration of wild chum salmon fry at Fujitsuka Beach (southern limits of the distribution) repeats about two months after the end of the stocking, and they are adapted to a warmer environment than fry in northern areas, such as Hokkaido.

\section{REFERENCES}

Irie, T. 1990. Ecological studies on the migration of juvenile chum salmon, Oncorhynchus keta, during early ocean life. Bull. Seikai Natl.Fish.Res. Inst. 68: 1-142. (In Japanese with English abstract) 
Miyakoshi, Y., H. Urabe, H. Saneyoshi, T. Aoyama, H. Sakamoto, D. Ando, K. Kasugai, Y. Mishima, M. Takada, and M. Nagata. 2012. The occurrence and run timing of naturally spawning chum salmon in northern Japan. Environ. Biol. Fish. 94(1): 197-206.

Morita, K., and K. Ohkuma. 2015. Chum salmon: existence and conservation of wild fish that have persisted under hatchery programs. Jap. J. Ichthyol. 62: 189-195.

Nagata, M., Y. Miyakoshi, H. Urabe, M. Fujiwara, Y. Sasaki, K. Kasugai, M. Torao, D. Ando, and M. Kaeriyama. 2012. An overview of salmon enhancement and the need to manage and monitor natural spawning in Hokkaido, Japan. Environ. Biol. Fish. 94(1): 311-323.

Salo, E.O. 1991. Life history of chum salmon (Oncorhynchus keta). In Pacific salmon life histories. Edited by C. Groot and L. Margolis. Univ. British Columbia Press, Vancouver. pp. 231-309. 